\title{
Density and Biomass of the Ichthyofauna of a Natal Littoral Reef
}

\author{
P. F. Berry*, R. P. van der Elst, P. Hanekom**, C. S. W. Joubert and M. J. Smale*** \\ Oceanographic Research Institute, P. O. Box 10712 Marine Parade, 4056 Durban, South Africa
}

\begin{abstract}
Visual censusing methods were employed over 2 consecutive years to estimate density and biomass of the ichthyofauna on a rocky littoral reef. A total of 66 teleost and 2 elasmobranch species was recorded of which 10 accounted for over $98 \%$ of the total mean dry biomass of $15.1 \mathrm{~g} \mathrm{~m}^{-2}$. The only truly resident species were Scartella cristata and Pictiblennius cornutus which together comprised more than two thirds of the total biomass. Besides the blennies, Sarpa salpa was most important in terms of mean biomass $\left(1.1 \mathrm{~g} \mathrm{~m}^{-2}\right)$ and Pomadasys olivaceum in terms of mean density $\left(0.9 \mathrm{~m}^{-2}\right)$. Carnivores far outnumbered both herbivores and omnivores but the latter predominated in terms of biomass. It is concluded that shallow reefs on the east coast of South Africa, such as the one studied, represent an important source of concentrated food production to inshore teleosts. Caloric values are given for 18 teleost species.
\end{abstract}

\section{INTRODUCTION}

This paper contributes to the overall results of an ecological study of the community inhabiting a small, rocky reef in the surf zone on the Natal coast undertaken by the Oceanographic Research Institute, Durban (ORI), South Africa, between 1975 and 1980. Organisms for which results have already been published are mussels (Berry, 1978), rock lobsters (Smale, 1978; Berry and Smale, 1980), teleosts (Joubert and Hanekom, 1980; Joubert, 1981), microorganisms (Schleyer, 1980, 1981), octopuses (Buchan and Smale, 1981), and detritivores (Berry, 1982)

The study reef, which is situated in front of the ORI and is hence known as the ORI Reef, is in the littoral zone and heavy surf breaks over it continuously. It extends at right angles from the shore for about $80 \mathrm{~m}$, is about $20 \mathrm{~m}$ wide and has a total area of $1646 \mathrm{~m}^{2}$. The top of the reef is level and it has steep undercut sides which vary in height from $2.5 \mathrm{~m}$ to $0 \mathrm{~m}$ when completely covered by sand. The tidal regime is a $1.2 \mathrm{~m}$ semi-diurnal cycle which, at HWS, covers the reef to a depth of about $1.8 \mathrm{~m}$. At LWS some of the high points

\footnotetext{
- Western Australian Museum, Francis Street, Perth, Western Australia 6000

- Department of Oceanography, University of Cape Town, Rondebosch, 7700 South Africa

-. Port Elizabeth Museum, P. O. Box 13147, Humewood, 6013, South Africa
}

are exposed. The reef is composed of sandstone, has the morphology of a wave-cut platform and supports a rich sessile fauna typical of this type of habitat in Natal. It has an algal covering of closely cropped turf, seldom exceeding $1 \mathrm{~cm}$ in height and is isolated from the nearest rocky reef in the vicinity by at least $200 \mathrm{~m}$ of open sand

Water conditions on the ORI Reef are subtropical with an annual mean temperature $(1975 / 80)$ of $22.35^{\circ} \mathrm{C}$ (range 19.8 to $25.3^{\circ} \mathrm{C}$ ), and a mean salinity of $35.2 \% \mathrm{~S}$.

A feature of littoral reefs on the Natal coast is the abundance and diversity of the fish fauna, and the objective of this study was to record and quantify the species present on the ORI Reef.

\section{MATERIALS AND METHODS}

High turbidity and strong wave action around the ORI Reef limited the techniques that could be employed to quantify the ichthyofauna. The only method found to be suitable to obtain estimates of numbers and sizes of fishes was visual census, similar to that employed by Brock (1954), Miller and Geibel (1973), Russell (1977) and Russell et al. (1978). Parallel transects along the reef surface were marked by large steel coach-bolts bearing conspicuously coloured, numbered labels which were driven into its surface at $4 \mathrm{~m}$ intervals, thus providing reference points for 
divers. Censusing occurred on every day that conditions were suitable for diving. This resulted in a sampling frequency of 2.1 dives per month over a 2 y period, though in 4 mo conditions did not permit any samplings. A total of 184 diver hours was spent censusing, i.e. an average of 9.2 for each of the 20 mo sampled, during which a total of more than 11,000 fish were counted. Horizontal visibility was estimated making use of reference pegs on the reef. During 45 dives this averaged $4.3 \mathrm{~m}$ with a range of 0 to $18 \mathrm{~m}$ (zero visibility was caused temporarily by breaking surf).

The numbers of each species and estimates of size, by $5 \mathrm{~cm}$ size classes, were scored on perspex slates by a team of 5 SCUBA divers. Sides and top of the reef were censused separately. The procedure was for the divers first to swim singly along the sides of the reef - separated by 5 min intervals - recording all species, except Pomadasys olivaceum, which was so abundant that it was counted separately on a return swim along the same route. Fish frequenting the top of the reef were then recorded by all the divers swimming abreast at the same time down transects along the length of the reef. The width of each transect was dependent on the visibility at the time but it was ensured that the entire reef top was covered synchronously by all the divers. Each diver thus ended up with an individual census of number and sizes of each species present on the sides and portion of the top of the reef from which a final estimate for the whole reef was made, based on all the divers' counts and following a debriefing session immediately after the dive. In most instances the size estimates of each diver correlated closely, but in cases where discrepancies occurred, and to keep a check on accuracy of size frequency estimates, fish were periodically speared for measurement.

The biomass of each species was calculated by converting the estimated size frequency distribution using length-weight relationships previously determined or obtained from the literature (Table 2). Energy equivalents were obtained by combustion in an adiabatic bomb calorimeter and values that differed by less than $5 \%$ were used to determine means.

A somewhat different visual census technique was employed to quantify blennies (Joubert, 1980). These cryptic fishes were counted by placing a $25 \mathrm{~cm} \times 25 \mathrm{~cm}$ quadrat at random along transects on the top of the reef. The quadrat had a crushed mussel suspended in the middle, the scent of which caused these voracious, opportunistic carnivores to emerge, unaffected by the presence of the diver, enabling a count to be made. Censusing without the crushed mussel in the quadrat yielded densities that were 24 to $54 \%$ lower, but even these were probably substantially higher than would have been obtained without a quadrat at all, the presence of which was in itself attractive to blennies. Thus it is considered that the method did not seriously underestimate these cryptic fish which has been the experience in studies which relied solely on scanning the substrate for them (e.g. Christensen and Winterbottom, 1981). The number of quadrats placed each census to obtain $\pm 20 \%$ of the mean at the $95 \%$ confidence level was determined using graphs produced by Cassel (1965). Monthly samples (approximately 200 fish representing less than $0.5 \%$ of the total population) were also captured using a baited hoop net from which mean weight was determined and biomass estimated, assuming that the samples were representative of the population counted.

\section{RESULTS}

A total of 66 teleost and 2 elasmobranch species was recorded from the ORI Reef (Tabie 1). Of the 30 teleost species for which biomass data were available, 10 accounted for $98 \%$ of the total biomass; these were: Acanthurus triostegus, Coracinus multifasciatus, Diplodus sargus, Epinephelus andersoni, Pictiblennius cornutus, Pomadasys olivaceum, Rhabdosargus sarba, Sarpa salpa, Scartella cristata and Trachinotus africanus.

The total mean dry biomass of the ichthyofauna on the reef was $15.1 \mathrm{~g} \mathrm{~m}^{-2}$ ( $\equiv 341.7 \mathrm{~kJ} \mathrm{~m}^{-2}$ from the mean caloric value in Table 2, i.e. $22628 \mathrm{~J} \mathrm{~g}^{-1}$ ). This is a slight underestimate because the biomass of 35 uncommon species was not included as no length' weight relationships were available for them. However, considering the low density of the species involved, the effect on the overall biomass estimate is thought to be negligible. The blennies Pictiblennius cornutus and Scartella cristata were more important than all other species combined and had a total mean dry biomass of $11.1 \mathrm{~g} \mathrm{~m}^{-2}$ as opposed to $4.0 \mathrm{~g} \mathrm{~m}^{-2}$ for the others. Of these Sarpa salpa constituted the greatest biomass, and Pomadasys olivaceum the highest numbers. Excluding blennies, the individual totals for the $2 \mathrm{y}$ were $3.3 \mathrm{~g} \mathrm{~m}^{-2}(1975 / 1976)$ and $4.8 \mathrm{~g} \mathrm{~m}^{-2}(1976 /$ 1977). (The biomass of the blennies was determined over one year only).

Feeding categories have been allocated to those species for which our own data were available (Table 1). Of the 10 most important species in terms of biomass, 6 were carnivores, 2 omnivores and 2 herbivores. Omnivores were most important in terms of biomass $\left(8.21 \mathrm{~g} \mathrm{~m}^{-2}\right.$ or $\left.56.3 \%\right)$ with the blenny Scartella cristata comprising most $\left(7.3 \mathrm{~g} \mathrm{~m}^{-2}\right)$ of the relatively high omnivore biomass figure. Carnivores $\left(5.35 \mathrm{~g} \mathrm{~m}^{-2}\right.$ or $\left.36.1 \%\right)$ of which Pictiblennius cornutus comprised $3.8 \mathrm{~g} \mathrm{~m}^{-2}$, were more important than herbivores which comprised only $1.28 \mathrm{~g} \mathrm{~m}^{-2}$ or $8.6 \%$. 
Table 1. Mean density, mean biomass and trophic category of fishes on the ORI Reef over 2 y (November 1975-January 1977) (c carnivore, o omnivore, h herbivore). "Sampled over 1 year only

\begin{tabular}{|c|c|c|c|c|c|c|}
\hline \multirow[t]{2}{*}{ Species } & \multirow[t]{2}{*}{$\begin{array}{l}\text { Trophic } \\
\text { category }\end{array}$} & \multirow{2}{*}{$\begin{array}{l}\text { Mean monthly } \\
\text { density } \mathrm{m}^{-2} \\
\left(\mathrm{x} 10^{-3}\right)\end{array}$} & \multirow[t]{2}{*}{$\begin{array}{c}\text { Density range } \\
\mathrm{m}^{-2}\left(\times 10^{-3}\right)\end{array}$} & \multirow{2}{*}{$\begin{array}{l}\text { No. of months } \\
\text { recorded out } \\
\text { of } 20 \text { samples }\end{array}$} & \multicolumn{2}{|c|}{$\begin{array}{l}\text { Mean biomass }(\mathrm{g}) \\
\mathrm{mo}^{-1} \mathrm{~m}^{-2}\left(\times 10^{-3}\right)\end{array}$} \\
\hline & & & & & Wet & Dry \\
\hline Abudefduf sp. & - & 0.03 & $0-\quad 0.6$ & 6 & - & - \\
\hline A. sexfasciatus & - & 0.001 & $0-\quad 0.6$ & 1. & - & - \\
\hline A. sordidus & 0 & 0.9 & $0-13.4$ & 12 & 88.5 & 30.0 \\
\hline A. vaigiensis & C & 16.5 & $0-404.6$ & 15 & 48.5 & 15.5 \\
\hline Acanthurus fuliginosus & - & 0.01 & $0-\quad 0.6$ & 1 & - & - \\
\hline A. lineatus & $\mathrm{H}$ & 0.01 & $0-4.3$ & 6 & - & - \\
\hline A. triostegus & $\mathrm{H}$ & 8.0 & $0.6-34.6$ & 20 & 543.0 & 171.5 \\
\hline Ambassis natalensis & C & 4.5 & $91.7-607.5$ & 2 & - & - \\
\hline Aspidontus sp. & C & 0.01 & $0-\quad 0.6$ & 1 & - & - \\
\hline Blennius fascigula & C & 0.01 & $0-\quad 0.6$ & 1 . & - & - \\
\hline Bothidae & $\mathrm{C}$ & 0.05 & $0-\quad 0.6$ & 3 & - & - \\
\hline Caranx sp. & $\mathrm{C}$ & 0.02 & $0-\quad 0.6$ & 1 & - & - \\
\hline Caranx sem & $\mathrm{C}$ & 0.25 & $0-10.9$ & 4 & 80.5 & 22.0 \\
\hline Canthigaster solandri & - & 0.01 & $0-\quad 0.6$ & 1 & - & - \\
\hline Chaetodon sp. & - & 0.01 & $0-\quad 0.6$ & 1 & - & - \\
\hline C. blackburnii & $\mathrm{C}$ & 0.05 & $0-\quad 0.6$ & 2 & - & - \\
\hline Chelonodon patoca & $\mathrm{C}$ & 2.0 & $0-13.7$ & 14 & - & - \\
\hline Coracinus capensis & $\mathrm{O}$ & 0.02 & $0-\quad 1.2$ & 3 & 1.6 & 0.5 \\
\hline C. multifasciatus & $\mathrm{C}$ & 11.0 & $0.6-62.8$ & 17 & 1690.0 & 654.5 \\
\hline Dinoperca petersii & - & 0.5 & $0-\quad 8.2$ & 6 & 37.5 & 11.0 \\
\hline Diplodus sargus & $\mathrm{O}$ & 50.0 & $0-291.7$ & 18 & 3130.0 & 950.0 \\
\hline Drepane punctata & - & 0.03 & $0-\quad 1.2$ & 1 & 30.0 & 10.0 \\
\hline Elops machnata & $\mathrm{C}$ & 0.08 & $0-\quad 0.1$ & 2 & 32.0 & 9.5 \\
\hline Epinephelus andersoni & C & 4.6 & $0-19.1$ & 18 & 267.0 & 71.5 \\
\hline E. grammatophorus & C & 0.03 & $0-\quad 0.6$ & 1 & - & - \\
\hline E. guaza & $\mathrm{C}$ & 0.03 & $0-\quad 0.6$ & 2 & 0.3 & 0.1 \\
\hline Gertes oyena & C & 0.01 & $0-0.6$ & 1 & - & - \\
\hline Gymnothorax sp. & - & 0.3 & $0-1.8$ & 9 & - & - \\
\hline Heniochus acuminatus & $\mathrm{C}$ & 0.08 & $0-0.6$ & 2 & - & - \\
\hline Leiognathus equulus & - & 0.02 & $0-\quad 1.2$ & 2 & 0.4 & 0.05 \\
\hline Lethrinus sp. & C & 0.1 & $0-0.6$ & 1 & - & - \\
\hline Liza tricuspidens & - & 0.1 & $0-4.8$ & 2 & 56.0 & 16.3 \\
\hline Lutjanus sp. & C & 1.2 & $0-6.8$ & 5 & - & - \\
\hline L. fulviflamma & C & 0.05 & $0-1.8$ & 2 & - & - \\
\hline Monishia william & - & 0.01 & $0-\quad 0.6$ & 2 & - & - \\
\hline Monodactylus argenteus & $\mathrm{C}$ & 0.9 & $0-37.1$ & 2 & 62.5 & 20.0 \\
\hline Neoscorpis lithophilus & $\mathrm{H}$ & 1.61 & $0-21.9$ & 10 & 90.3 & 24.15 \\
\hline Omobranchus banditus & - & 0.01 & $0-\quad 0.6$ & 1 & - & - \\
\hline Otolithes ruber & $\mathrm{C}$ & 0.0 & $0-23.91$ & 1 & - & - \\
\hline Pagellus natalensis & - & 0.2 & $0-5.46$ & 4 & - & - \\
\hline Parvoclinus laurentii & - & 0.01 & $0-0.6$ & 1 & - & - \\
\hline Pictiblennius cornutus & $\mathrm{C}$ & 12400.0 & $4.9-11.6$ & $12^{\circ}$ & 17090.0 & 3790.0 \\
\hline Platycephalus indicus & $\mathrm{C}$ & 0.01 & $0-\quad 0.6$ & 1 & - & - \\
\hline Plectorhynchus chubbi & C & 0.2 & $0-\quad 4.9$ & 6 & - & - \\
\hline Plotosus limbatus & - & 0.01 & $0-\quad 0.6$ & 1 & - & - \\
\hline Pomacanthus sp. & $\mathrm{C}$ & 0.01 & $0-\quad 0.6$ & 1 & - & - \\
\hline Pomadasys commersonni & $\mathrm{C}$ & 0.2 & $0-\quad 8.5$ & 5 & 65.0 & 20.0 \\
\hline P. multimaculatum & $\mathrm{C}$ & 0.1 & $0-\quad 0.6$ & 1 & 1.5 & 0.5 \\
\hline P. olivaceum & $\mathrm{C}$ & 936.2 & $0-12960.5$ & 16 & 1090.0 & 265.0 \\
\hline Pomatomus saltator & $\mathrm{C}$ & 0.2 & $0-6.1$ & 2 & 75.0 & 20.0 \\
\hline Pseudorhombus arsius & - & 0.02 & $0-\quad 0.6$ & 1 & - & - \\
\hline Pseudupeneus fraterculus & $\mathrm{C}$ & 1.1 & $0-12.8$ & 13 & 60.5 & 16.0 \\
\hline Pterois volitans & C & 0.03 & $0-\quad 0.6$ & 1 & - & - \\
\hline Rhabdosargus auriventris & $\mathrm{C}$ & 0.05 & $0-0.6$ & 2 & - & - \\
\hline R. holubi & $\mathrm{C}$ & 0.03 & $0-\quad 0.6$ & 2 & 4.1 & 1.0 \\
\hline R. sarba & $\mathrm{C}$ & 4.5 & $0-60.75$ & 10 & 1245.0 & 370.0 \\
\hline Rhonciscus anas & $\mathrm{C}$ & 0.04 & $0-\quad 0.6$ & 1 & - & - \\
\hline Sarpa salpa & $\mathrm{H}$ & 35.1 & $0-536.4$ & 12 & 3550.0 & 1110.0 \\
\hline Scartella cristata & 0 & 11500.0 & $4.8-9.6$ & 12 . & 27960.0 & 7260.0 \\
\hline Scomberoides tala & $\mathrm{C}$ & 0.5 & $0-\quad 0.6$ & 4 & 110.0 & 30.0 \\
\hline Secutor insidiator & - & 80.3 & $0-1215.1$ & 5 & - & - \\
\hline Strongylura leiurus & - & 0.2 & $0-12.1$ & 3 & 6.5 & 2.0 \\
\hline Thalassoma sp. & - & 0.01 & $0-0.6$ & 4 & - & - \\
\hline Trachinotus africanus & C & 1.1 & $0-60.75$ & 3 & 695.0 & 205.0 \\
\hline Umbrina robinsoni & -- & 0.1 & $0-3.0$ & 2 & - & - \\
\hline Valamugil buchanani & $\mathrm{H}$ & 0.03 & $0-15.2$ & 1 & 0.05 & 0.015 \\
\hline Carcharhinus obscurus & $\mathrm{C}$ & 0.01 & $0-\quad 0.6$ & 1 & 33.4 & 9.7 \\
\hline Torpedo sinuspersici & $\mathrm{C}$ & 0.07 & $0-0.6$ & 5 & 105.0 & 30.5 \\
\hline
\end{tabular}


Table 2 presents the mean caloric values for 18 species of reef fish. The highest ash-free value was $31581 \mathrm{~J} \mathrm{~g}^{-1}$ for Acanthurus fuliginosus, the lowest $24428 \mathrm{~J} \mathrm{~g}^{-1}$ for Pomadasys olvaceum, with a mean of $27568 \mathrm{~J} \mathrm{~g}^{-1}$. However, some species were sexually mature while others were immature and this may have affected the values.

A feature of the findings is the seasonal influx of newly recruited juvenile fishes. In order to illustrate this, diversity indices have been calculated. As the shortcomings of such indices are well known (Peet, 1975), no attempt has been made to correlate them with those of reefs in other regions. However, a monthly comparison between indices for the ORI Reef alone does provide a useful method of detecting trends in fish community structure (Allen and Horn, 1975).

Margalef's index of species richness (Margalef, 1958) and Pielou's index of evenness (Pielou, 1966) were calculated on a monthly basis and plotted together with the number of species (Fig. 1). In terms of species richness there are 2 periods when the diversity is noticeably increased: June and December/January. It is particularly during the winter change in species richness that the ORI Reef fish community is subject to greatest change in numbers as seen from the considerable decrease in Pielou's evenness index during that period. Such a decrease is not only due to an increase in the number of species (as during June) but also reflects a change in the actual number of specimens present. This occurs especially during July, as a direct result of massive recruitment of young Pomadasys olivaceum.

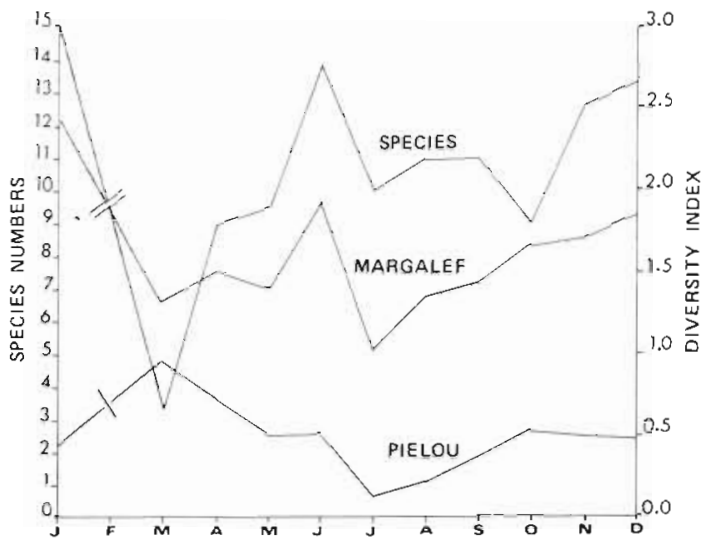

Fig. 1. Species richness and 2 diversity indices plotted on a monthly basis for the total ORI Reef fish count

Of the 10 most important species in terms of biomass, Scartella cristata and Pictiblennius cornutus were the only truly resident species on the reef in that, once settled as postlarvae, they are non-migratory. Juveniles and adults were recorded throughout the year, the mean individual dry mass being $0.6 \mathrm{~g}$ and $0.3 \mathrm{~g}$ for each species respectively.

Acanthurus triostegus, both juveniles and adults, was recorded throughout the year. One shoal of adults, identifiable by scarred individuals, was present for 9 consecutive mo indicating a high degree of residency. Mean individual dry mass was $21 \mathrm{~g}$.

Diplodus sargus adults and juveniles were recorded primarily in summer though some were present throughout the year (Fig. 2), including very small post-

Table 2. Mean caloric value and length weight conversion of 18 species of ORI Reef fish

\begin{tabular}{|c|c|c|c|c|c|c|}
\hline Species & No. & $\mathrm{J} \mathrm{g}^{-1}$ & $\mathrm{~J} \mathrm{~g}^{-1}$ (ash-free & \multicolumn{3}{|c|}{ Fork length $(\mathrm{L})$ in $\mathrm{mm}$ to weight (W), in $\mathrm{g}$} \\
\hline Abudefduf sordidus & 6 & 23891 & 30697 & $\mathrm{~W}=.000002997$ & $\mathrm{~L}^{3.525}$ & (this study) \\
\hline A. vaigiensis & 2 & 21139 & 25930 & $W=.00001396$ & $\mathrm{~L}^{318}$ & (this study) \\
\hline Acanthurus fuliginosus & 1 & 27059 & 31581 & & - no dat & $a-$ \\
\hline A. triostegus & 13 & 23043 & 28310 & $W=.000014$ & $L^{3152}$ & (this study) \\
\hline Ambassis natalensis & 10 & 22018 & 27969 & $W=.0000308$ & $\mathrm{~L}^{2.794}$ & (this study) \\
\hline Coracinus multifasciatus & 30 & 21276 & 26340 & $W=.000012$ & $\mathrm{~L}^{3.152}$ & (Joubert, 1981) \\
\hline Diplodus sargus & 16 & 21881 & 26632 & $W=.000033$ & $\mathrm{~L}^{2.994}$ & (Joubert, 1981) \\
\hline Dinoperca petersii & 2 & 23215 & 28975 & $W=.000018$ & $\mathrm{~L}^{3.002}$ & (this study) \\
\hline Epinephelus andersoni & 24 & 22992 & 27569 & $W=.000041$ & $L^{2800}$ & (this study) \\
\hline Plectorhyncus chubbi & 1 & 21242 & 24886 & & - no dat & $a-$ \\
\hline Monodactylus argenteus & 11 & 24182 & 28188 & $W=.0000014$ & $\mathrm{~L}^{3.538}$ & (this study) \\
\hline Neoscorpis Iithophilus & 10 & 21133 & 25696 & $W=.000014$ & $\mathrm{~L}^{3.080}$ & (Joubert, 1981) \\
\hline Pictiblennius cornutus & 24 & 23354 & 28337 & $W=.00000079$ & $\mathrm{~L}^{3.105}$ & (Joubert, 1980) \\
\hline Pomadasys olivaceum & 23 & 20507 & 24428 & $W=.000014$ & $\mathrm{~L}^{3.070}$ & (Joubert, 1981) \\
\hline Pseudopeneus fraterculus & 3 & 21591 & 25995 & $W=.0000054$ & $\mathrm{~L}^{3.291}$ & (this study) \\
\hline Sarpa salpa & 24 & 21910 & 26853 & $W=.000059$ & $\mathrm{~L}^{2.793}$ & (Joubert, 1981) \\
\hline Scartella cristata & 26 & 22308 & 27785 & $W=.00000082$ & $L^{3135}$ & (Joubert, 1980) \\
\hline Scomberoides tala & 2 & 24570 & 30054 & $W=.0000141$ & $\mathrm{~L}^{2.9156}$ & (this study) \\
\hline
\end{tabular}


larvae; this indicates that this species recruits to the reef at a very early age. It is, however, a highly mobile fish, particularly the adults, which occur in loose shoals or singly, and individuals were not resident for more than a few days at the most. The small shoaling

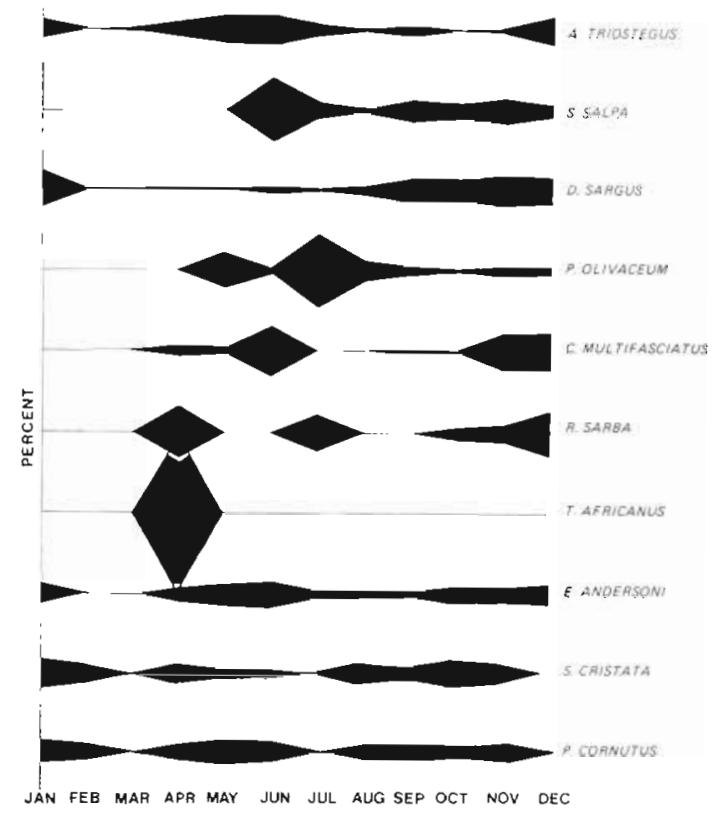

Fig. 2. Kite diagrams of the monthly fish counts expressed as a percentage of the total count for 10 top species

juveniles feed on organisms in the water column, whereas adults feed largely on sessile organisms (see also Joubert and Hanekom, 1980). The mean individual dry mass was $19 \mathrm{~g}$.

Sarpa salpa is a shoaling fish and a winter migrant to Natal waters from the Cape. It was recorded on the reef mainly from May to December (Fig. 2) when the population comprised an apparently fairly resident shoal of about 100 adults, some scarred individuals being recognisable throughout their stay. Mean individual dry mass was $32 \mathrm{~g}$.

Although some Pomadasys olivaceum were recorded in all months; a most noticeable influx of postlarvae and juveniles occurred during May and July. This transient shoaling species constantly moved on and off the reef where it fed on midwater organisms, confirmation of which was obtained from stomach content analyses (Joubert and Hanekom, 1980). The adults occur offshore on deeper reefs where they are known to spawn. Mean individual dry mass was $0.3 \mathrm{~g}$.

Epinephelus andersoni, a solitary predator, was recorded in all months except March. It settles on the reef as a juvenile approximately $1.5 \mathrm{~cm}$ long and probably has a high degree of residency until subadult (approx. $25 \mathrm{~cm}$ ) at which size it becomes evident in fishermen's catches on deeper offshore reefs. Mean individual dry mass was $15 \mathrm{~g}$.

Coracinus multifasciatus occurred throughout the year either individually or in loose shoals, and although some newly settled juveniles were seen, the population largely comprised adults which were very active and constantly moved on and off the reef. Mean individual dry mass was $59 \mathrm{~g}$.

Trachinotus africanus is a highly mobile shoal fish. Some adults and subadults visited the reef irregularly to feed on the mussel Perna perna. However, it was an influx of juveniles in April that accounted for $98 \%$ of this species biomass (Fig. 2). Mean individual dry mass was $186 \mathrm{~g}$.

Rhabdosargus sarba is also a highly mobile shoal fish; it visited the reef to feed on Perna perna. Adults and subadults were recorded in all months except August and September. Mean individual dry mass was $82 \mathrm{~g}$.

All the other species recorded on the ORI Reef are regarded as being 'transients' (Russell, 1977) which were non-resident and passing through the area. The majority of these were juveniles or subadults.

It should be noted that the estimates of density and biomass are based entirely on daylight observations as similar census methods could not be employed at night. However, on 5 night dives, complete inactivity or disappearance of the species commonly present during daylight was observed, with the exception of Monodactylus argenteus, which was present and active on each occasion.

\section{DISCUSSION}

This paper does not intend to evaluate visual censusing as a technique per se. However, since quantitative estimates of the ichthyofauna in a turbulent wave zone do not appear to have been attempted previously, some assessment of the reliability of the results is required. Censuses by individual divers were usually very similar, but were not directly comparable because each diver did not necessarily see all fish present or the same fish, the final estimate being the composite result of censuses after debriefing. Nevertheless, in more than $50 \%$ of censuses the coefficient of variation (CV) between divers was less than $100 \%$ and the overall CV throughout the period was $107 \%$ (range $=22 \%$ to $173 \%)$. Checking size estimates by shooting fish demonstrated a high degree of accuracy which did not exceed more than one $5 \mathrm{~cm}$ size class on either side of the true length class. Although a higher frequency of censusing may have improved the estimates this was already at its maximum, being limited by suitable diving conditions. 
Christensen and Winterbottom (1981) discuss problems inherent in visual censusing of teleosts and showed that in intertidal rock pools, visual censusing underestimated the fauna to varying degrees according to habits of the species when compared with a subsequent census using an ichthyocide. They calculated correction factors for groups of species according to habits, but concluded that these would vary for different species, observers and areas. For reasons already outlined it is considered that the blennies were not underestimated in this study. On the basis that specimens of the other species on the ORI Reef were generally substantially larger than those on which Christensen and Winterbottom based their study, that repeated dives showed that recognisable shoals had been accurately censused and that algal cover and shelter is minimal on the ORI Reef, it is considered that application of their correction factors to the ORI Reef population would result in an overestimate of density. However, if applied to the 8 most important species listed on page 50 (excluding the blennies) it results in an increase in mean standing stock of $\sim 12 \%$ or $\sim 1.8 \mathrm{~g}$ $\mathrm{m}^{-2}$ dry weight.

This study showed that on average teleost dry mass is equivalent to $29.1 \%$ of wet mass. This factor has been used to convert wet weight values given by other authors to dry weights for comparison with the results of this study. Our results are comparable with those of Brock (1954) and Bardach (1959) who found that the standing stock of tropical inshore reef fish in Hawaii was $18.0 \mathrm{~g} \mathrm{~m}^{-2}$ and in Bermuda $14.3 \mathrm{~g} \mathrm{~m}^{-2}$ respectively. McFarland (1965) dealing with fish in the subtropics, reports that the biomass in the surf at Mustang Island, Texas, was $0.8 \mathrm{~g} \mathrm{~m}^{-2}$ in winter and $3.4 \mathrm{~g} \mathrm{~m}^{-2}$ in summer These values are considerably lower than the biomass figure for ORI Reef fish, and this is probably due to the fact that McFarland's (1965) study area had a sandy bottom. Miller and Geibel (1973) showed that the standing stock of kelp bed fish off the Californian coast varied between $0.3 \mathrm{~g} \mathrm{~m}^{-2}$ and $32.6 \mathrm{~g} \mathrm{~m}^{-2}$. The biomass of temperate reef fish at Goat Island off the New Zealand coast varies according to the type of relief and extent of algal cover and ranges from 0.3 to $30 \mathrm{~g} \mathrm{~m}^{-2}$ (Russell, 1977). Holm (1977) calculated that the standing stock of fish in a tropical lagoon in the upper Florida Keys was $2.9 \mathrm{~g} \mathrm{~m}^{-2}$, while Quast (1968) estimated that the biomass of fish in the kelp beds of southern California was $10.2 \mathrm{~g} \mathrm{~m}^{-2}$. It therefore appears that the mean standing stock of fish on the ORI Reef $\left(15.1 \mathrm{~g} \mathrm{~m}^{-2}\right)$ is comparatively high and well within the range of values found elsewhere.

This study has shown the great importance of 2 blenny species both in terms of numbers and biomass on the ORI Reef. Even when taken individually, Scartella cristata has a greater biomass than all the other species combined, and the biomass of Pictiblennius cornutus was almost as great. It is not known to what extent this represents a natural situation as species such as Rhabdosargus sarba, Trachinotus africanus, Epinephelus andersoni and others are subjected to intense angling pressure on the Natal coast and could well have declined in abundance and mean size.

An interesting feature of the ichthyofauna on the ORI Reef is its seasonal variation. There is a distinct trend for fish to be present either during winter, summer or both. Sudden recruitment such as in Pomadasys olivaceum, Diplodus sargus and Trachinotus africanus strongly suggest that the reef is of importance as a temporary nursery for juvenile fishes.

Fishermen's catches near the ORI Reef suggest that large predatory fish which do not rely on sight for feeding may come onto the reef at night. Examples of these are the kob Argyrosomus hololepidotus and the sharks Carcharhinus obscurus and Rhizoprionodon acutus. It seems unlikely that their inclusion would have greatly increased the total biomass estimate as the daylight results showed that small resident species constituted a greater component than larger transient predators. Nevertheless, these top carnivores may play an important role in export from the reef.

The role of the physical energy of the surf zone in promoting high biological productivity by filter feeders on the ORI Reef has been outlined by Berry (1982), who recorded a mean production rate of $1,255 \mathrm{~g}$ of dry flesh $\mathrm{m}^{-2} \mathrm{yr}^{-1}$ by the mussel Perna perna, the dominant filter feeder present. It is considered that the diversity and biomass of teleosts recorded here is associated with high concentrations and productivity of food organisms such as $P$. perna, the presence of which would also account for the predominance of carnivores in the population. We conclude that shallow reefs on the Natal coast, such as the ORI Reef, are of particular importance to juvenile teleosts as sources of concentrated food production.

Acknowledgements. This work was jointly supported by the South African Association for Marine Biological Research and the South African National Committee for Oceanographic Research. We thank Mrs. I. Ehrberg for use of unpublished data on biomass of blennies.

\section{LITERATURE CITED}

Allen, L. G., Horn, M. H. (1975). Abundance, diversity and seasonality of fishes in Colorado lagoon, Alamites Bay, California. Estuar. coast. mar. Sci. 5: 371-380

Bardach, J. G. (1959). The summer standing crop of fish on a shallow Bermuda reef. Limnol. Oceanogr 4 (1): 77-85

Berry, P. F. (1978). Reproduction, growth and production in the mussel Perna perna (Linnaeus) on the east coast of South Africa. Investl Rep. oceanogr Res. Inst. (48): 1-28 
Berry, P. F. (1982). Biomass and density of detritivores on a littoral rocky reef on the Natal Coast, with an estimate of population production for the ascidian Pyura stolonifera. Investl Rep oceanogr Res. Inst. (53): 1-12

Berry, P. F., Smale, M. J. (1980). An estimate of production and consumption rates in the spiny lobster panulirus homarus on a shallow reef off the Natal Coast, South Africa. Mar. Ecol. Prog. Ser 2: 337-343

Brock, V E. (1954). A preliminary report on a method of estimating reef fish populations. J, Wildl. Mgmt 18: 297-308

Buchan, P. R., Smale, M. J. (1981). Estimates of biomass, consumption and production of Octopus vulgaris Cuvier off the east coast of South Africa. Investl Rep. oceanogr. Res. Inst. (50): $1-9$

Cassel, E. A. (1965). Rapid graphical method for estimating the precision of direct microscope counting data. Appl. Microbiol. 13 (3): 293-296

Christensen, M. S., Winterbottom, R. (1981). A correction factor for, and its application to, visual census of littoral fish. S. Afr. J. Zool. 16 (2): 78-79

Holm, R. F. (1977). The standing crop of fishes in a tropical marine lagoon. Fla Sci. 40 (3) : 258-261

Joubert, C. S. W., Hanekom, P. B. (1980). A study of feeding in some inshore reef fish of the Natal Coast, South Africa. S. Afr. J. Zool. 15: 262-271

Joubert, C. S. W. (1981). Aspects of the biology of five species of inshore reef fishes on the Natal Coast, South Africa. Investl Rep. oceanogr. Res. Inst. (51): 1-16

Joubert, I. (1980). The biology of Blennius cristatus L. and Blennius cornutus L. (Teleostei-Blennoiodea) on a Natal
Reef. M. Sc, thesis, Department of Biological Sciences, University of Natal, Durban

Margalef, R. (1958). Information theory in ecology. Gen. Syst. 3: $36-71$

Miller, D. J., Geibel, J. J. (1973). Summary of blue rockfish and lingcod histories; a reef ecology study; and giant kelp, Macrocystis pyrifera, experiments in Monterey Bay, California. Fish. Bull. Calif. (158): 1-137

McFarland, W. N. (1965). Seasonal change in the number and biomass of fishes from the surf at Mustang Island, Texas. Publs Inst. mar Sci. Univ. Tex. 9: 91-105

Peet, R. K. (1975). Relative diversity indices. Ecology 56 : $496-498$

Pielou, E. C. (1966). The measurement of diversity in different types of biological collections. J. theor. Biol. 13: 131-144

Quast, J. C. (1968). Estimates of the populations and the standing crop of fishes. In: North, W. J., Hubbs, C. L. (eds.) Utilization of kelp bed resources in southern California. Fish Bull. Calif. (139): 57-59

Russell, B. C. (1977). Population and standing crop estimates for rocky reef fishes of north-eastern New Zealand. N. Z. Jl mar Freshwat. Res. 11 (1): 23-26

Schleyer, M. H. (1980). A preliminary evaluation of heterotrophic utilization of a labelled algal extract in a subtidal reef environment. Mar Ecol. Prog. Ser. 3: 223-229

Schleyer, M. H. (1981). Microorganisms and detritus in the water column of a subtidal reef of Natal. Mar. Ecol. Prog. Ser $4: 307-320$

Smale, M. J. (1978). Migration, growth and feeding in the Natal rock lobster Panulirus homarus (Linnaeus). Investl Rep. oceanogr. Res. Inst. (47): 1-56 